\title{
PENGARUH MODEL PEMBELAJARAN DRAMATIC LEARNING BERBANTUAN BONEKA TANGAN TERHADAP KETERAMPILAN BERBICARA
}

\author{
Komang Sri Ustari \\ Universitas Pendidikan Ganesha \\ Email: sriustari71@gmail.com
}

\begin{abstract}
Abstrak
Penelitian ini bertujuan untuk mengetahui perbedaan keterampilan berbicara Bahasa Indonesia antara kelompok siswa yang mengikuti model pembelajaran dramatic learning berbantuan boneka tangan dan kelompok siswa yang dibelajarkan dengan pembelajaran konvensional pada siswa kelas III SD di Gugus III Kecamatan Busungbiu. Jenis penelitian ini adalah eksperimen semu dengan rancangan non-equivalend posttest only control group design. Populasi penelitian ini adalah siswa kelas III SD di Gugus III Kecamatan Busungbiu. Sampel penelitian ini adalah kelompok siswa kelas III SD N 2 Umejero dan SD N 3 Umejero. Istrumen pengumpulan data yang digunakan dalam penelitian ini adalah lembar observasi. Teknik analisis data yang digunakan adalah uji-t. Berdasarkan hasil analisis diperoleh rata-rata skor kelompok eksperimen yaitu 19,35 dan kelompok kontrol yaitu 14,43. Hasil penelitian menunjukkan bahwa terdapat perbedaan keterampilan berbicara antara kelompok siswa yang mengikuti model pembelajaran dramatic learning berbantuan boneka tangan dan kelompok siswa yang dibelajarkan dengan pembelajaran konvensional. Perbedaan tersebut ditunjukan dari hasil perhitungan uji-t diperoleh thitung $=6,276$ pada taraf signifikansi $5 \%$ dengan $\mathrm{dk}=39$ didapat $\mathrm{t}_{\text {tabel }}=2,021$. Kriteria pengujian $\mathrm{t}_{\text {hitung }}>\mathrm{t}_{\mathrm{tabel}}(6,276>2,021)$ maka $\mathrm{H}_{0}$ ditolak. Hasil penelitian menunjukan bahwa terdapat perbedaan yang signifikan keterampilan berbicara Bahasa Indonesia antara kelompok siswa yang dibelajarkan dengan model pembelajaran Dramatic Learning berbantuan Boneka Tangan dengan kelompok siswa yang dibelajarkan dengan pembelajaran konvensional. Dapat disimpulkan bahwa penerapan model pembelajaran Dramatic Learning berbantuan Boneka Tangan berpengaruh positif terhadap keterampilan berbicara Bahasa Indonesia pada siswa kelas III SD di Gugus III Kecamatan Busungbiu, Kabupaten Buleleng Tahun Pelajaran 2017/2018.
\end{abstract}

Kata kunci: dramatic learning, boneka tangan, keterampilan berbicara

\begin{abstract}
This study aimed to determine the differences of various Indonesian speaking skills between groups of student who followed the learning model of dramatic learning that assisted hand puppet and a group of students which were taught by conventional learning in third grade students of elementary school at Cluster III Busungbiu Subdistrict. This type of study was quasi experiment with a non-equivalent of posttest only control group design. The population of this study was the third grade students of elementary school in Cluster III Busungbiu Sub-district. The sample of this study was group of third grade students in Elementary School 2 Umejero and Elementary School 3 Umejero. The instrument of data collection used in this study was the observation sheet. The technique of data analysis used was t-test. Based on the result of analysis , the average score of the experimental group was 19,35 and the control group was 14,43 . The result of study showed that there were differences in speaking skill between group of students who followed the learning model of dramatic learning that assisted hand puppet and the group of students who were taught by conventional learning. The difference was shown from the result of t-test calculation obtained tct $=6,276$ at significance level $5 \%$ with $\mathrm{dk}=39$ obtained ttable $=2,021$. Test criteria tcount $>$ ttable (6.276> 2.021) then $\mathrm{H} 0$ rejected. The result showed that there were significant differences in Indonesian speaking skills between group of students who were taught by Dramatic Learning that assisted hand puppet learning model with group of students who were taught by conventional learning. It can be concluded that the application of Dramatic Learning that assisted Hand Puppet positively affected to Indonesian speaking skills in third grade students at Cluster III Busungbiu Sub-district, Buleleng District Lesson Year 2017/2018.
\end{abstract}

Keywords: dramatic learning, hand puppet, speaking skill

\section{Pendahuluan}

Pembelajaran Bahasa Indonesia di SD merupakan wadah untuk mengembangkan kemampuan siswa dalam menggunakan bahasa sebagai alat komunikasi. Menurut Ramlan, dalam Dibia 2014:2 "Bahasa merupakan alat kamunikasi dan alat interaksi manusia. Bahasa memegang peranan penting dalam mengembangkan potensi 
manusia dalam berbagai bidang kehidupan”. Bahasa tidak hanya berfungsi sebagai alat komunikasi, tetapi juga sarana yang tepat untuk mengungkapkan berbagai macam gagasan.

Oleh karena itu, pelajaran Bahasa Indonesia diberikan dengan tujuan agar anak memiliki kemampuan berkomunikasi secara efektif dan efesien sesuai dengan etika yang berlaku, baik secara tertulis atau lisan. Menurut Tarigan, 2015 "Ada empat keterampilan berbahasa, yang meliputi: keterampilan menyimak (Listening Skills), keterampilan berbicara (Speaking Skills), keterampilan membaca (Reading Skills), dan keterampiln menulis (Writing Skills)". Berarti dalam mata pelajaran Bahasa Indonesia terdapat empat keterampilan yang harus dikuasi oleh siswa. Keterampilan menyimak dan berbicara merupakan kegiatan komunikasi dua arah yang langsung serta merupakan komunikasi tatap muka atau face to face communication.

Salah satu keterampilan yang penting dipelajari oleh siswa adalah keterampilan berbicara. Keterampilan berbicara merupakan salah satu keterampilan berbahasa yang sangat penting dalam meningkatkan keaktifan dan kemampuan siswa dalam berkomunikasi. Sumantri, dkk, 2014:34 menyatakan bahwa "Berbicara merupakan bagian dari keterampilan berbahasa lisan lainnya adalah menyimak". Kedua keterampilan ini memiliki keterkaitan. Peristiwa berbicara selalu diikuti oleh peristiwa menyimak atau peristiwa menyimak pasti ada dalam peristiwa berbicara. Oleh karna itu, berbicara dan menyimak adalah peristiwa berbahasa lisan yang saling melengkapi.

Keterampilan berbicara merupakan keterampilan yang harus dikuasi oleh setiap siswa, Menurut Tarigan 2015:1 menyatakan "Semakin terampil seseorang berbahasa semakin cerah dan jelas pula jalan pikirannya". Ini berarti keterampilan berbicara sangat mempengaruhi jalan pikiran seseorang. Dengan menguasi keterampilan berbicara, siswa akan mampu menyampaikan pendapat dan pikirannya sesuai dengan konteks pembicaraan.

Kenyataan saat ini dalam pembelajaran Bahasa Indonesia, keterampilan berbicara siswa masih sangat kurang banyak dari siswa yang belum bisa menunjukkan keterampilan berbicaranya dengan baik. Mutu pendidikan pada jenjang sekolah dasar khususnya keterampilan berbicara sebagai sarana berkomunikasi yang masih menjadi masalah oleh siswa. Keterampilan berbicara yang dimiliki oleh siswa bervariasi mulai dari tahap yang baik, sedang, gagap dan ada yang kurang. Ada beberapa siswa yang mudah lupa dengan hal yang ingin dibicarakan dengan temannya, bahkan ada siswa yang merasa gugup jika disuruh berbicara karena mereka takut salah dalam berbicara.

Berdasarkan hasil observasi yang telah dilakukan pada tanggal 12 Desember 2017 dengan siswa kelas III semester dua (Genap) di SD Gugus III Kecamatan Busungbiu, diketahui bahwa kemampuan berbicara siswa masih di tahap yang cukup, kurang dan masih ada siswa yang masih gugup. Hal ini dapat dilihat saat proses pembelajaran berlangsung, khususnya kegiatan berbicara. Dari delapan sekolah yang diobservasi, kebanyakan siswa yang malu-malu dan gugup ketika diminta untuk berbicara, dan beberapa siswa yang seolah-olah tidak fokus dalam menerima pembelajaran. Selain itu, masih terdapat banyak siswa yang belum mampu untuk mengungkapkan pendapat dan pemikirannya.

Selain observasi, dilakukan juga wawancara pada tanggal 12 Desember 2017 dengan guru mata pelajaran Bahasa Indonesia (Guru Kelas) di SD Gugus III Kecamatan Busungbiu. Berdasarkan hasil wawancara yang dilakukan dengan guru pelajaran Bahasa Indonesia (Guru Kelas), guru menyatakan bahwa dalam proses pembelajaran hanya menggunakan metode ceramah, metode tanya jawab, dan metode penugasan dalam mengajar. Model yang digunakan dalam proses pembelajaran ini bisa disebut pembelajaran konvensional. Pembelajaran konvensional merupakan pembelajaran yang berupa penerapan metode ceramah, Tanya jawab dan penugasan yang dilakukan guru secara terus menerus (Rasana, 2009). Jika kegiatan pembelajaran dilakukan dengan cara tersebut maka dalam proses pembelajaran akan membosankan. Penggunaan model pembelajaran ini digunakan oleh guru untuk menuntaskan materi yang cukup banyak dalam waktu yang sangat singkat. Dan guru juga kurang mengetahui model-model pembelajaran termasuk model Dramatic Learning.

Dramatic Learning merupakan salah satu model pembelajaran dimana siswa dilibatkan langsung dalam proses pembelajaran, Menurut Brunetiere dan Balthazar 1996:3 dalam Aris Shoimin 2014;71 menyatakan bahwa "Model Dramatic Learning yaitu drama adalah kesenian yang melukiskan sifat dan sikap manusia dengan action perilaku". Ini berarti siswa dapat bermain peran dalam proses pembelajaran. Menurut Hamzah 2009 menyatakan bahwa "Bermain peran di buat berdasarkan asumsi bahwa sangat mungkin menciptakan analogi otentik ke dalam suatu situasi permasalahan kehidupan nyata". Kemudian bermain peran dapat mendorong siswa mengekspresikan diri, sehingga dengan bermain peran siswa dapat memahami pelajaran khususnya dalam keterampilan berbicara. Dengan model dramatic learning akan lebih baik jika berbantuan media, yaitu dengan media boneka tangan. Boneka tangan merupakan salah satu media pendukung dalam proses pembelajaran dan memiliki beragam bentuk warna yang menarik. Sehingga siswa akan lebih aktif dalam proses pembelajaran berlangsung.

Pengimplementasian metode yang sama secara terus-menerus, tanpa adanya pemilihan model pembelajaran yang variatif membuat siswa menjadi membosankan dan melemahkan semangat siswa dalam proses pembelajaran. Jika siswa tidak dilibatkan langsung dalam prose pembelajaran melainkan hanya sebagai penerima pesan saja. Hal ini sangat bertolak belakang dengan hal yang seharusnya dilakukan oleh guru, 
seharusnya guru menciptakan pembelajaran yang aktif dan lebih menuntut siswa untuk turut serta dalam proses pembelajaran, sehingga siswa mampu mempraktikkan cara berbicara yang baik dan benar. Guru jarang memanfaatkan media dalam mengajar karena sedikit tersedianya media disekolah. Pengunaan media yang menarik akan membuat siswa lebih semangat dan fakus dalam proses pembelajaran berlangsung. Hal tersebut dapat menyebabkan nilai keterampilan berbicara siswa rendah.

Berdasarkan pencatatan dokumen yang dilakukan pada tanggal 12 Desember 2017, diketahui bahwa nilai rata-rata keterampilan berbicara siswa di SD Gugus III Kecamatan Busungbiu dari 8 sekolah, masih banyak siswa yang memperoleh nilai di bawah kriteria ketuntasan minimal (KKM), yaitu 58,27\% siswa masih dibawah KKM sedangkan yang memenuhi KKM hanya 58,27\%.

Rata-rata nilai keterampilan berbicara siswa masih banyak yang belum mencapai ketuntasan dan berada di bawah KKM yang telah ditentukan. Rendahnya rata-rata nilai keterampilan berbicara berdasarkan hasil wawancara dengan guru kelas III dapat dilihat dari keaktifan siswa saat proses pembelajaran di dalam kelas. Ada beberapa fakor yang juga berpengaruh terhadap rendahnya hasil rata-rata nilai keterampilan berbicara siswa.

Berdasarkan observasi, wawancara dan pencatatan dokumen yang telah dilakukan, dapat disimpulkan bahwa kurangnya keterampilan berbicara siswa di kelas III di SD Gugus III kecamatan Busungbiu. Hal ini disebabkan oleh dua faktor yaitu: yang pertama faktor internal, meliputi: perasaan gugup, kurang percaya diri dan malu-malu, sedangkan yang kedua faktor eksternal, meliputi: kurangnya pemilihan model yang inovatif serta kurangnya penggunaan media pembelajaran dalam proses pembelajaran. Penggunaan media pembelajaran bagi siswa sekolah dasar dirasa sangat tepat, karena sesuai dengan tehap perkembangannya mereka masih berada pada tahap operasional konkret. Keberadaan media sebagai suatu benda yang nyata diharapan siswa akan sangat membantu proses penyampaian materi.

Salah satu media yang tepat digunakan pada pembelajaran Bahasa Indonesia khususnya materi berbicara adalah media boneka tangan. (Dina indriana 2011:3 dalam widowati 2016) menyatakan bahwa "Media merupakan sebuah alat yang dapat digunakan untuk menyampaikan pesan pada proses pembelajaran" jadi media adalah alat yang digunakan oleh guru untuk menyampaikan pesan dalam proses pembelajaran.. Boneka adalah suatu benda yang pada umumnya disukai oleh anak-anak, sehingga pemilihan boneka tangan ini dirasa sangat tepat karena dapat menarik perhatian siswa. (Daryanto 2013:33 dalam Karimah 2016) menyatakan bahwa "Menggunakan media boneka tangan tidak memerlukan keterampilan yang rumit, efisien waktu, tempat, biaya dan persiapan". Boneka tangan juga dapat mengembangkan kreativitas dan imajinasi anak dalam suasana gembira, sehingga pembelajaran yang berlangsung akan menyenangkan. Maka dengan media boneka tangan pembelajaran Bahasa Indonesia khususnya pada keterampilan berbicara akan meningkatkan antosias siswa dalam proses pembelajaran.

Berdasarkan uraian di atas, dipandang perlu diadakan penelitian lebih lanjut tentang "Pengaruh Model Pembelajaran Dramatic Learning Berbantuan Boneka Tangan Terhadap Keterampilan Berbicara Bahasa Indonesia Siswa Kelas III Semester II SD di Gugus III Kecamatan Busungbiu Kabupaten Buleleng Tahun Pelajaran 2018/2019".

Penelitian ini bertujaun untuk mengetahui perbedaan keterampilan berbicara siswa pada mata pelajaran Bahasa Indonesia antara siswa yang dibelajarkan dengan menggunakan model pembelajaran Dramatic Learning berbantuan media boneka tangan dengan siswa yang dibelajarkan menggunakan pembelajaran konvensional pada siswa kelas III di SD Gugus III Kecamatan Busungbiu tahun pelajaran 2017/2018.

\section{Metode}

Penelitian ini merupakan penelitian eksperimen. Jenis penelitian ini adalah eksperimen semu (quasi experiment). Rancangan penelitian ini menggunakan. Penelitian ini mengikuti desain penelitian kuasi eksperimen dengan rancangan non-equivalent post test only control group design. Tempat pelaksanaan penelitian ini adalah di SD Gugus III Kecamatan Busungbiu, Kabupaten Buleleng rentang waktu semester ganjil tahun pelajaran 2017/2018. Penelitian ini dimulai dari pengumpulan data awal melalui kegiatan observasi, wawancara, dan pencatatan dokumen sampai dengan penyusunan proposal. Kelompok eksperimen diberikan perlakuan yaitu dibelajarkan dengan model pembelajaran Dramatic Learning, sedangkan kelompok kontrol dibelajarkan dengan pembelajaran konvensional.

Populasi pada penelitian ini adalah siswa kelas III pada tahun pelajaran 2017/2018 Sekolah Dasar di Gugus III Kecamatan Busungbiu tepatnya pada SD yang berada di Desa Umejero dengan jumlah siswa 137 orang yang dibelajarkan kurikulum satuan tingkat pendidikan (KTSP) dan kurikulum 2013. Sebelum menentukan sampel yang akan diambil dalam penelitian ini, terlebih dahulu harus dilakukan uji kesetaraan populasi. Dalam menghitung kesetaraan kelompok sampel digunakan rumus Analisi Varians Satu Jalur (ANAVA klasifikasi tunggal).

Berdasarkan hasil perhitungan dengan mnggunakan analisis varian (ANAVA) pada taraf signifikan 5\% diperolah $\mathrm{F}_{\text {hitung }}$ sebesar 0,99. Sedangkan nilai $\mathrm{F}$ tabel sebesar 2,08, dengan demikian, $\mathrm{F}_{\text {hitung }}<\mathrm{F}_{\text {tabel }}$, sehingga $\mathrm{H}_{0}$ diterima. Dari pernyataan tersebut dapat ditarik kesimpulan bahwa $\mathrm{H}_{0}$ yang menyatakan tidak terdapat perbedaan 
yang signifikan keterampilan berbicara siswa kelas III di SD Gugus III Kecamatan Busungbiu, Kabupaten Buleleng adalah diterima. Jadi dapat diinterprestasikan bahwa sampel setara.

Setelah diperoleh hasil perhitungan uji kesetaraan, selanjutnya kedelapan SD tersebut dirandom untuk menentukan kelas eksperimen dan kelas kontrol. Cara yang digunakan untuk menentukan sampel adalah masingmasing kelas III di tiap sekolah diberikan nomor urut. Selanjutnya dipilih dua kelas secara random untuk dijadikan sampel. Kemudian dari kedua kelas yang dipilih, di rondom lagi dengan pengundingan untuk menentukan kelas ekspemen dan kelas kontrol. Melalui rondem sampling, ditetapkan kelas III di SD Negeri 2 Umejero yang berjumlah 20 orang sebagai kelompok eksperimen, yang diberikan perlakuan berupa model pembelajaran Dramatic Learning berbantuan boneka tangan dan kelas III di SD Negeri 3 Umejero berjumlah 21 orang sebagai kelompok kontrol yang diberi perlakuan berupa pembelajaran konvensional.

Data yang dikumpulkan dalam penelitian ini adalah keterampilan berbicara Bahasa Indonesia siswa kelas III. Metode pengumpulan data yang digunakan adalah metode non-test (lembar observasi keterampilan berbicara). Pengumpulan data yang akan digunakan oleh peneliti melihat variabel terikat dari penelitian tersebut adalah keterampilan berbicara, maka pengumpulan data menggunakan metode non-test yaitu lembar observasi keterampilan berbicara. Dalam penelitian ini, keterampilan berbicara siswa selama proses pembelajaran berlangsung dapat dinilai dalam beberapa aspek, yaitu intonasi, ekspresi berbicara, kelancaran, dan lafal. Setiap indikator-indikator tersebut memiliki skor maksimal yaitu 5 dan skor minimal yaitu 1. Jika siswa memperoleh skor tertinggi 5 dari 4 indikator maka jumlah skor yang diperoleh siswa sebesar 20.

Data yang diperoleh dianalisis dengan menggunakan metode analisis deskriptif dan analisis inferensial. Analisis deskripsi bertujuan untuk mengetahui tinggi maupun rendahnya hasil belajar IPA siswa kelas III pada kelompok eksperimen maupun kelompok kontrol. Pada analisis deskriptif diperoleh hasil mean, median, modus, standar deviasi, dan varians. Sedangkan, uji inferensial meliputi uji prasyarat hipotesis dan uji hipotesis. Uji prasyarat meliputi uji normalitas sebaran data dan uji homogenitas varians. Uji hipotesis pada penelitian ini menggunakan uji-t untuk mengetahui ada atau tidaknya perbedaan hasil belajar pada kelompok eksperimen dan kelompok kontrol. Rumus uji-t yang digunakan adalah polled varians. Pemilihan rumus ini didasarkan pada ketentuan $\mathrm{n}_{1} \neq \mathrm{n}_{2}$, data berdistribusi normal, dan varians homogen.

\section{Hasil dan Pembahasan}

Berdasarkan hasil analisis data dengan analisis statistik deskritif pada kelas eksperimen dan kontrol maka diperoleh hasil sebagai berikut. Adapun deskripsi pada kedua kelompok disajikan pada Tabel 01

Tabel 01

Rekapitulasi Hasil Perhitungan Skor Keterampilan Berbicara Kelompok Eksperimen Dan Kelompok Kontrol

\begin{tabular}{|c|c|c|}
\hline \multirow{2}{*}{ Statistik } & \multicolumn{2}{|c|}{ Hasil Keterampilan Berbicara } \\
\cline { 2 - 3 } & Kelompok Eksperimen & Kelompok Kontrol \\
\hline Mean & 19,35 & 14,43 \\
\hline Median & 20 & 14 \\
\hline Modus & 22 & 5,257 \\
\hline Varian & 7,397 & 2,293 \\
\hline Standar Deviasi & 2,719 & 18 \\
\hline Skor Maksimal & 23 & 11 \\
\hline Skor Minimum & 15 & 8 \\
\hline Rentangan & 9 & \\
\hline
\end{tabular}

Berdasarkan tabel di atas rata-rata skor keterampilan berbicara kelompok eksperimen sebesar 19,35. Skor rata-rata keterampilan berbicara kelompok eksperimen yang dibelajarkan dengan model pembelajaran dramatic learning adalah sebesar 19,35. Jika rata-rata keterampilan berbicara Bahasa Indonesia kelompok eksperimen dikonversikan ke dalam Penilaian Acuan Patokan (PAP) Skala Lima berada pada kategori tinggi. Sedangkan pada kelompok kontrol sebesar 14,43. Skor rata-rata keterampilan berbicara Bahasa Indonesia kelompok kontrol yang dibelajarkan dengan pembelajaran konvensional adalah sebesar 14,43. Jika rata-rata keterampilan berbicara Bahasa Indonesia kelompok kontrol dikonversikan ke dalam Penilaian Acuan Patokan (PAP) Skala Lima berada pada kategori sedang.

Sebelum melakukan uji hipotesis terlebih dahulu dilakukan uji prasyarat analisis yaitu uji normalitas dan uji homogenitas. Ringkasaan hasil uji normalitas kelompok eksperimen dan kelompok kontrol dapat dilihat pada tabel 02 
Tabel 02

Hasil Uji Normalitas Sebaran Data

Kelompok Eksperimen dan Kelompok Kontrol

\begin{tabular}{|c|c|c|c|}
\hline Kelompok Data & L & $\begin{array}{c}\text { Nilai kritis dengan taraf } \\
\text { signifikansi 5\% }\end{array}$ & Keterangan \\
\hline Kelompok eksperimen & 0.1920 & $0,05 \%$ & Normal \\
\hline Kelompok kontrol & 0,1881 & & Normal \\
\hline
\end{tabular}

Berdasarkan hasil perhitungan analisis statistic Liliefors dengan perhitungan manual, diperoleh $\mathrm{p}$ kelompok eksperimen adalah 0,1051. Hal ini berarti, angka signifikansi kelompok eksperimen lebih besar dari pada 0,05 (p $>0,05)$, sehingga data hasil post-test kelompok eksperimen berdistribusi normal. Sedangkan pada kelompok kontrol diperoleh p kelompok kontrol adalah 0,1610. Hal ini berarti, angka signifikansi kelompok eksperimen lebih besar dari pada 0,05 ( $\mathrm{p}>0,05)$, sehingga data hasil post-test kelompok kontrol berdistribusi normal.

Setelah dihitung normalitas data kemudian akan diuji homogenitas terhadap varians pasangan antara kelompok eksperimen dan kelompok kontrol dengan kriteria data homogeny jika $F_{\text {hitung }}<\mathrm{F}_{\text {tabel. }}$ Ringkasan hasil uji homogenitas varians antar kelompok eksperimen dan kontrol disajikan pada Tabel 03.

Tabel 03

Hasil Uji Homogenitas Varians

Kelompok Eksperimen dan Kelompok Kontrol

\begin{tabular}{|c|c|c|c|}
\hline Sumber data & $\mathrm{F}_{\text {hitung }}$ & $\begin{array}{c}\text { Nilai kritis dengan taraf } \\
\text { signifikasi 5\% }\end{array}$ & Keterangan \\
\hline $\begin{array}{c}\text { Post- test kelompok } \\
\text { eksperimen dan } \\
\text { kelompok kontrol }\end{array}$ & 1,41 & $0,05 \%$ & Homogen \\
\hline
\end{tabular}

Berdasrkan tabel diatas, diperolehhasil post -test kelompok ekperimen dan kelompok kontrol dengan $\mathrm{p}$ $=1,41$. Hal ini berarti, angka signifikan $>0,05(\mathrm{p}>0,05)$, sehingga varians data hasil post-test kelompok eksperimen dan kelompok kontrol homogen.

Berdasarkan uji prasyarat analisis data, diperoleh bahwa data keteramplan berbicara siswa kelompok eksperimen dan kelompok kontrol normal dan homogen. Kemudian dilanjutkan dengan pengujian hipotesis penelitian. Pengujian hipotesis tersebut menggunakan uji-t dengan rumus polled varians dengan ketentuan pengujian hipotesis, yaitu $\mathrm{H}_{1}$ diterima jika $\mathrm{t}_{\text {hitung }}>\mathrm{t}_{\text {tabel }}$ dan $\mathrm{H}_{0}$ diterima jika $\mathrm{t}_{\text {hitung }} \leq \mathrm{t}_{\text {tabel }}$. Pengujian dilakukan pada taraf signifikansi 5\% dengan $\mathrm{dk}=\left(\mathrm{n}_{1}+\mathrm{n}_{2}\right)-2$. Ringkasan uji hipotesis disajikan pada Tabel 04

Tabel 04

Hasil Uji Hipotesis dengan Uji-t

\begin{tabular}{|c|c|c|c|c|c|c|}
\hline Kelompok & $\mathrm{N}$ & $\mathrm{Db}$ & $\mathrm{Mean}$ & $\mathrm{S}^{2}$ & $\mathrm{t}_{\text {hitung }}$ & $\mathrm{t}_{\text {tabel }}$ \\
\hline Eksperimen & 20 & \multirow{3}{*}{39} & 19,35 & 7,397 & & \\
\cline { 1 - 3 } Kontrol & 21 & & 14,43 & 5,257 & 6,28 & 2,021 \\
\hline
\end{tabular}

Berdasarkan hasil perhitungan uji-t di atas, diperoleh $t_{\text {hit }}$ adalah 6,276 Sedangkan $t_{\text {tabel }}$ dengan taraf signifikansi $5 \%$ dan $\mathrm{db}=(20+21)-2=39$ adalah 2,021. Hal ini berarti, $\mathrm{t}_{\text {hitung }}$ lebih besar dari $\mathrm{t}_{\text {tabel }}(6,28>2,021)$, sehingga $\mathrm{H}_{0}$ ditolak dan $\mathrm{H}_{1}$ diterima. Jadi, dapat disimpulkan terdapat perbedaan yang signifikan keterampilan berbicara Bahasa Indonesia siswa antara kelompok siswa yang mengikuti pembelajaran dengan model pembelajaran Dramatic Learning dan kelompok siswa yang mengikuti pembelajaran konvensional di kelas III SD Gugus III Kecamatan Busungbiu Kabupaten Buleleng Tahun Pelajaran 2017/2018.

\section{Pembahasan}

Berdasarkan hasil penelitian, terdapat perbedaan yang signifikan pada keterampilan berbicara antara kelompok siswa yang dibelajarkan dengan model pembelajaran dramatic learning dan kelompok siswa yang dibelajarkan dengan model konvensional. Perbedaan tersebut disebabkan oleh adanya penggunaan model dramatic learning berbantuan boneka tangan. Model dramatic learning ini telah melatih siswa untuk mengembangkan keterampilan berbahasanya, khususnya dalam keterampilan berbicara. Dikatakan melatih keterampilan berbahasa siswa, karena model dramatic learning ini dimana siswa dilibatkan langsung dalam proses pembelajaran dan melibatkan siswa sebagai pelakon sehingga memberikan pemahaman, pengertian, dan pengetahuan pada siswa.

Menurut Tarigan (2015) yang menyatakan bahwa "Diperlukan latihan-latihan dan praktik untuk menguasi suatu keterampilan berbahasa". Maka dari itu, siswa harus menguasi empat keterampilan dalam 
berbahasa, salah satunya yaitu keterampilan berbicara. Dalam model dramatic learning ini dimana siswa terlibat langsung untuk melakukan sebuah kata, konsep, perilaku, kalimat, ide, pengalaman atau kejadian dengan memanfaatkan teknik teater dan mengembangkan permainan, kegiatan berdrama memberikan banyak kesempatan untuk siswa mengungkapkan dan mengembangkan kreativitasnya (Kirikkale, University 2008).

Hal tersebut sesuai dengan pendapat Isnani (2013) yang menyatakan bahwa "Metode bermian peran menunjukkan pembelajaran keterampilan berbicara melalui metode bermain peran berdasarkan naskah drama menunjukkan peningkatan keterampilan berbicara siswa. Peningkatan ditunjukkan dengan hasil nilai keterampilan berbicara siswa. Peningkatan yang terjadi yaitu, (1) rata-rata nilai pratindakan, (2) rata-rata nilai evaluasi siklus I sebesar 77,0 dengan persentase ketuntasan sebesar 51\%, (3) rata-rata nilai evaluasi siklus II sebesar 81,5 dengan persentase ketuntasan $88 \%$ ".

Selanjutnya, adanya penggunaan boneka tangan untuk manarik perhatian siswa supaya dalam proses pembelajaran siswa lebih tertarik untuk berbicara di depan kelas. (Yosastra, dkk. 2013) mengemukakan bahwa "Boneka jari adalah permainan yang menggunakan jari-jari tangan yang dipasangkan boneka berukuran mini dengan karakter tertentu." Selanjutnya, (Tompkins dan Hoskisson 1995, p.174 dalam Mariana, 2015) menyatakan bahwa "Boneka tangan sederhana yang disediakan dapat memberikan kesempatan kepada anak untuk mengembangkan kreativitas dan keterampilan dramtiknya. Karena boneka tangan merupakan salah satu media pendukung dalam proses pembelajaran, juga memiliki beragam bentuk dan warna yang menarik sehingga siswa akan lebih tertarik untuk belajar.boneka tangan dapat digunakan tidak hanya dalam aktivitas drama saja, tetapi juga sebagai suatu cara untuk mengembangkan keterampilan berbahasa siswa, salah satunya dalam keterampilan berbicara.

Disamping itu, penggunaan boneka tangan memberikan kesan yang menyenangkan pada diri siswa. Hal tersebut terbukti saat pembelajaran berlangsung, siswa lebih bersemangat dan antusias dalam mengikuti pembelajaran karena boneka tangan tersebut berukuran mini dengan karakter tertentu dan warna yang menarik. Selanjutnya, dikatakan pula bahwa boneka itu secara khusus dapat digunakan oleh anak-anak pemalu untuk menumbuhkan keberanian berbicara. boneka tangan dapat mengefesienkan waktu dalam proses pembelajaran di kelas, serta mampu mengasah kecakapan berbahasanya dikatakan pula bahwa boneka itu secara khusus dapat digunakan oleh anak-anak pemalu untuk menumbuhkan keberanian berbicara.

Lebih lanjut, kemampuan guru dalam menyampaikan drama berpengaruh terhadap lafal saat berdrama. Hal ini terjadi karena guru sebagai model yang diperhatikan, diamati, dan ditiru oleh siswa. Sehingga, jika siswa di mintak untuk maju ke depan kelas untuk berdrama dengan model dramatic learning berbantuan boneka tangan dengan lafal diikuti gerak dari boneka tangan tersebut. Hal ini sejalan dengan pendapat Amalia dan Sa"diyah (2015) yang menyatakan bahwa " bahasa lisan guru serta penggunaan bahasa tubuh dapat mempelajari jalan cerita". Dengan demikian, penting bagi guru untuk melatih lafal yang sesuai dengan drama agar siswa mudah meniru dan mempraktekkannya saat berdrama.

\section{Simpulan dan Saran}

Berdasarkan hasil penelitian dan analisis data, dapat disimpulkan bahwa terdapat perbedaan yang signifikan keterampilan berbicara Bahasa Indonesia antara kelompok siswa yang dibelajarkan dengan model pembelajaran dramtic learning berbantuan boneka tangan dengan kelompok siswa yang dibelajarkan dengan pembelajaran konvensional pada siswa kelas III SD di Gugus III Kecamatan Busungbiu tahun pelajaran 2017/2018. Perbedaan tersebut ditunjukan dari hasil analisis diperoleh rata-rata skor kelompok eksperimen yaitu 19,35 berada pada kategori tinggi dan kelompok kontrol yaitu 14,43 berada pada kategori sedang. Hasil penelitian menunjukkan bahwa terdapat perbedaan yang signifikan keterampilan berbicara antara kelompok siswa yang mengikuti model pembelajaran dramatic learning berbantuan boneka tangan dan kelompok siswa yang dibelajarkan dengan pembelajaran konvensional. Perbedaan tersebut ditunjukan dari hasil perhitungan uji-t diperoleh $\mathrm{t}_{\text {hitung }}=6,276$ pada taraf signifikansi $5 \%$ dengan $\mathrm{dk}=39$ didapat $\mathrm{t}_{\text {tabel }}=2,021$. Kriteria pengujian $\mathrm{t}_{\text {hitung }}$ $>\mathrm{t}_{\text {tabel }}(6,276>2,021)$ maka $\mathrm{H}_{0}$ ditolak dan $\mathrm{H}_{1}$ diterima. Yang artinya terdapat perbedaan yang signifikan keterampilan berbicara Bahasa Indonesia antara kelompok siswa yang dibelajarkan dengan model pembelajaran Dramatic Learning berbantuan Boneka Tangan dengan kelompok siswa yang dibelajarkan dengan pembelajaran konvensional. Dapat disimpulkan bahwa penerapan model pembelajaran Dramatic Learning berbantuan Boneka Tangan berpengaruh positif terhadap keterampilan berbicara Bahasa Indonesia pada siswa kelas III SD di Gugus III Kecamatan Busungbiu, Kabupaten Buleleng Tahun Pelajaran 2017/2018.

Untuk itu penelitian ini disaankan kepada siswa hendaknya selalu aktif dan termotivasi untuk terus mengembangkan informasi yang diperoleh sehingga mendapatkan pengetahuan baru melalui pengamalan sendiri dan dapat mengembangkan pengetahuannya pada setiap mata pelajaran. Guru hendaknya melanjutkan pelaksanaan pembelajaran melalui model pembelajaran Dramatic Learning berbantuan boneka tangan dengan modifikasi agar sesuai dengan kondisi, materi, dan peserta didik. Kepala sekolah, hendaknya hasil penelitian ini dijadikan refrensi dan menjadikan hasil penelitian ini sebagai dasar kebijakan untuk membina guru dalam pengembangan model Dramatic Learning yang lebih kreatif dan inovatif. Kepada peneliti pemula agar hasil 
penelitian ini dapat digunakan sebagi acuan dan referensi awal untuk meneliti lebih lanjut mengenai peran guru sebagai model berbicara dan pengaruhnya terhadap interaksi guru dan siswa.

\section{Daftar Pustaka}

Agung, A.A. Gede. 2014.Metodologi Penelitian Pendidikan.Yogyakarta:Aditya Media Publishing.

Amalia, Taranindya Zulhi dan Zaimatus Sa"diyah. 2015.’Berbicara sebgai Metode Mengajar bagi Guru Raudhatul Athfal dalam Mengembangkan Kemampuan Dasar Bahasa Anak Usia Dini di Desa Ngembarejobae, Kudus”. Jurnal Ilmiah STAIN Kudus Jurusan Tarbiyah. Vol:3. No.2.

Dibia, I Ketut. 2014. Bahasa Indonesia Keilmuan: Singaraja: Universitas Pendidikan Ganesha.

Hamzah B Uno. 2009. Model Pembelajaran menciptakan Proses Belajar Mengajar yang Kreatif dan Efektif: Jakarta: Buni Aksara.

Isnani. 2013. "Peningkatan Keterampilan Berbicara Melalui Metode Bermain Peran pada siswa Kelas V sekolah Dasar Negeri 2 Wates. Jurnal PGSD Universitas Negeri Yogyakarta. (diakses tanggal 3 Maret 2018)

Karimah, Fahmi Nisa. 2016. "Pengaruh Penekatan SAVI dengan Media Boneka Tangan untuk Meningkatkan Keterampilan Bercerita Dongeng pada Siswa Kelas III SD Negeri Tanjungrejo”. Jurnal Ilmiah PGSD Universitas Sebelas Maret. (diakses tanggal 22 Januari 2018).

Koyan, I Wayan. 2012. Statistik Teknik Analisis Data Kuantitatif: Singaraja: Universitas Pendidikan Ganesha.

Mariana, Siti. 2015. "Pengaruh Penggunaan Media Boneka Tangan Terhadap Keterampilan Bercerita Siswa Kelas V SD Se-Gugus 4 Kecamatan Bantul”. Jurnal Ilmiah Universitas Negeri Yogyakarta. Volume 3 Nomor 2. (diakses tanggal 22 Januari 2018)

Rasana, I Dewa Putu Raka. 2009.Model-model Pembelajaran: Singaraja: Universitas Pendidikan Ganesha. Sumantri, dkk. 2014.Peningkatan Keterampilan Berhasa Indonesia: Singaraja: Universitas Pendidikan Ganesha. Shoimin, Aris. 2014.68 Model Pembelajaran Inovatif dalam Kurikulum 2013: Maguwoharjo: Ar-Ruzz Media. Tarigan, Henry Guntur. 2015.Berbicara Sebagai Suatu Keterampilan Berbahasa: Bandung: Angkasa Bandung. Widowati, Diah Ayu. 2016. "Pengaruh Media Boneka Tangan Terhadap Keterampilan Menyimak Cerita Kelas II B SD Negeri Margoyasan”. Jurnal Ilmiah PGSD Universitas Negeri Yogyakarta Jurusan PGSD, Edisi 27 Tahun ke-5. (diakses tanggal 22 Januari 2018)

Yosastra Oki, dkk. (2013). "Efektifitas Permainan Boneka Tangan Jari Untuk Meningkatkan Kemampuan Pengurangan Bilangan Bulat Bagi Anak Tunagrahita X”. E-Jupeku, Volume 2 nomor 3, Edidi khusus (hlm.671-681). (diakses tanggal 22 Januari 2018) 